\title{
Usability of Instructional Interface: Accessibility Strategies of Courseware Design for Distance Learning, Nigeria
}

\author{
Abdulrauf Tosho \\ Universiti Utara Malaysia, \\ Department of Media Technology, School of \\ Multimedia Technology and Communication, UUM, \\ 06010, Sintok, Kedah
}

\author{
Ariffin Abdul Mutalib \\ Sobihatun Nur Abdul Salam \\ Universiti Utara Malaysia, \\ Department of Media Technology, School of \\ Multimedia Technology and Communication, UUM, \\ 06010, Sintok, Kedah
}

\begin{abstract}
Usability is always the basic factor to be considered when developing any learning product. It attracts students to use the developed product such as courseware and help learners to gain more knowledge in learning. When usability strategies are considered in designing courseware, the courseware can be usable for the target users. Currently in Nigeria courseware are not fulfilling the requirement. Users are not happy with courseware; hence the usage is not encouraging, especially, in distance learning environment. Accordingly, this paper explains about the needs for determining the appropriate instructional interface elements using multimedia as part of usability strategies in courseware for distance learning. The study was carried out with fifteen academic staffs of a distance academic programme at university of Ilorin, Nigeria. Data were gathered through unstructured interviews. Having analyzed, the results show that there is a need for a study that determine the usability strategies for distance learning in Nigeria.
\end{abstract}

\section{Keywords}

Usability, courseware, instructional strategy, multimedia, distance learning, Inclusive Education System

\section{INTRODUCTION}

Teaching and learning in distance learning in Nigeria still run on traditional learning models with linear sequence and surface learning, whereas their counterparts in developed countries provide mostly high-impact audio-visual perception that motivates students to utilize the provided courseware. Most universities and higher learning institutions are now using multimedia and equivalent learning technologies to deliver part of their course contents to students. There is a growing need to offer greater flexibility in the strategies to improving learning in Nigeria distance learning. There are several challenges being faced in the use of available courseware in Nigeria's distance learning, which are discussed in the following:

i. Lack of a specific framework and policy implementation to encourage courseware design towards usability strategies for inclusive education system.

ii. The strategies for developing courseware towards universal design and multimedia instructional interface by dealing with the complex issues of multilingual national background. iii. Unavailability of instructional interface as usability strategies to enhance the courseware usage in distance learning.

Many factors were identified influencing the situation; nevertheless, lack of instructional strategies in the designed courseware is one of the main reasons. This is reflected in the diversity of languages in Nigeria, it has been avowed that product will not be embraced by users if it fails to enclose strategies that increase the usability and having a significance effect to them [10]. Similar study by [12] observed that low design of courseware toward usability strategies to enhance courseware usage is a continual problem in National Open University, Nigeria. He affirmed that the situation is critical for the headway of students and for the institution to fulfill its mission. The difficulty in user instructions that learners face when exploring courseware is indeed the greatest concern [4].

Also, it has been observed that most of the available coursewares are not utilized repetitively by users after the first viewing. Besides, when they read courseware, they do so strategically: skimming, skipping, and scanning. In addition, the study had indicated that the available coursewares in Nigeria distance learning have difficulty in searching for content. It could be interpreted that their perceived easy to use the courseware is very low and frustrating [12], [13].

All the facts indicate that the existing coursewares lack some strategies to enhance the learners' motivation when they are viewing the courseware and appropriate universal usability strategies on instruction interface design in developed courseware through users centered design is inappropriate.

On the other hand, enhancing courseware usage for teaching and learning can be seen through applicability of usability strategies into the courseware design. By incorporating certain instructional strategies, it can enhance on conquering courseware in student. So it should be implemented widely in distance learning programme in line with developed countries that require distance learning as to wake e-learning. It is hoped that the designing of courseware by considered instructional usability strategies concept, a quality education in Nigeria distance learning will be realized. Indirectly education vision in effort of distance learning increase rate wakes as much as courseware is going to succeed in this nearest period. Hence, the objective of this study is as stated in the next paragraph. 


\section{OBJECTIVE}

Based on the problem described in the previous section, together with the current state-of-the-art of education in Nigeria, this paper aims to determine the voice of people regarding the courseware in distance learning in Nigeria. Consequently, the activities as described in the following section were carried out, and the findings in the next section were deduced.

\section{METHODOLOGY}

\subsection{Data Collection}

Data for the study were collected through a series of unstructured interview. As a non-standardized interview type, it allows this study to prompt the respondents with more detailed responses where clarification is needed. It is sufficient because this study concerns on the meanings that people ascribed to a phenomenon. According to [1], interviewing is an energetic approach of helping people to make explicit things that have hitherto been implicit - to articulate their tacit perceptions, understandings and feelings.

The purpose of the interview is to determine whether the respondents are aware of the factors hindering the use of courseware and factors that are leading to or enhancing courseware usage, particularly, in relation to instructional and users' interface design of a distance academic programme at university of Ilorin, Nigeria. As to gather the data, fifteen academic staffs were involved from 24th to 29th of January 2013. The ten listed questions in Table 1 seek to determine the perception of respondents in issues such as respondents understanding towards the need to improving the usability strategies for courseware, understanding towards instruction design strategies, users interface design strategies, and integration of universal usability in the strategies to cater for both normal and disabled users.

This qualitative approach with fragment increasing use of perspective [2] by helping us to identify issues which are relevant for this study. As typical in unstructured interviews, pre-planned questions were asked, together with inquiring questions as needed to acquire more information, where it is relevant. The questions asked were as follows:

Table 1: Questions for respondents

\begin{tabular}{|l|l|}
\hline S/N0 & Questions \\
\hline 1 & $\begin{array}{l}\text { Do you have intention to develop courseware for your } \\
\text { course? }\end{array}$ \\
\hline 2 & $\begin{array}{l}\text { What are the factors that can motivate students to use } \\
\text { the courseware? }\end{array}$ \\
\hline 3 & $\begin{array}{l}\text { What are the instructional strategies that can enhance } \\
\text { the courseware usability? }\end{array}$ \\
\hline 4. & $\begin{array}{l}\text { Do you consider users understanding in the key points } \\
\text { presented in courseware pages? }\end{array}$ \\
\hline 5 & $\begin{array}{l}\text { Do you consider how to reduce waiting time in the } \\
\text { pages loading of designed courseware? }\end{array}$ \\
\hline 6 & $\begin{array}{l}\text { What are the strategies to make a courseware user- } \\
\text { friendly? }\end{array}$ \\
\hline 7 & $\begin{array}{l}\text { What are the universal strategic factors that can lead to } \\
\text { courseware usage? }\end{array}$ \\
\hline 8 & $\begin{array}{l}\text { What are the users interface strategies that can } \\
\text { enhance the courseware usage? }\end{array}$ \\
\hline
\end{tabular}

\begin{tabular}{|l|l|}
\hline 9. & $\begin{array}{l}\text { Do you consider the impaired (partial disabled) in your } \\
\text { developed courseware, for example people with low } \\
\text { vision problem? }\end{array}$ \\
\hline 10 & $\begin{array}{l}\text { Do you considerer the multimedia elements on } \\
\text { instructional and its effectiveness in your designed } \\
\text { courseware? }\end{array}$ \\
\hline
\end{tabular}

The fifteen respondents consisted of 9 male $(60 \%)$ and 6 female $(40 \%)$ of which 5 of them are lecturers with less than three years academic experience and 10 lecturers above three years academic experience. From the statistics, it was revealed that $80 \%$ of the respondents had participated in courseware design training while the remaining $20 \%$ adapt the available ones in the institution. The question as described above gathers analysis as stated in the next paragraph.

\section{FINDING}

Before the data collection began, the purpose of the research was fully explained to the respondents. Consequently, consent was given by all interviewees. They were recorded and transcribed.

Respondents' opinions on available courseware and the necessity to improve the instructional strategies towards multimedia elements to enhance the usability of courseware

Respondents generally expressed positive opinions about their experiences with the courseware. Negative views tended to be related to instructional design and usability problems in accessing and using the courseware. None of the respondents expressed a strong negative opinion regarding their experience in designing courseware, despite the fact that majority of the students were not using it as expected of this kind for the very first time. The respondents were able to share their experience about the research focus anytime the question asked. One respondent expressed the view about the important of courseware for teaching that"...courseware is very flexible to use for teaching". One more comment regarding convenience was expressed through “...to teach is one thing, but it's a different situation when learners have to study on your own. Then it's convenient with courseware or modules as a supplement, since students sort of have their own course content with them".

Another excerpt from respondents on the feeling of flexibility and enhanced learning is "...you are free to use it at any time available. It is very flexible and independent of time and place. This is a perfect method to teaching and learning what you need to learn".

The above points are reflected generally in the literature with teaching systems towards greater learner control over the learning process [5]; [19]. This enhanced learner control offers possibilities for improved learning. One respondent expressed her appreciation of working on her own as "...I like to interact with a computer and to work on my own. That is why the courseware was so exciting for me"

\section{Response towards Courseware Usability}

An issue of enhanced courseware usability choice was raised by several respondents. The usability design setting gave an extended opportunity to improving the use of the courseware application after the e-learning implementation.Another comment about enhancement of usability choice is noted in the following expression. 
"When you are sitting in a classroom, you don't always get every single message, and you still have the opportunity to learn it by accessing the courseware via internet and find all the information you need"

The respondents also expressed the view that they had gained insights into courseware activities that they could not have achieved without the direct experience with the distance learning activities by expressing "...The courseware has changed my attitude to distance learning because I have a son who attends high school where they use a Learning Management System [LMS]. I have never felt it was a respectable learning approach with the background from my own institution experience. Now I have changed my mind, because it worked out well. It works!"

The respondents expressed a general satisfaction with their courseware teaching experiences. The advantages of flexibility, convenience, enhanced learning are topics reported in the studies of [3]; [9] and [18]. Nevertheless, the aspects of enhanced courseware usability and strategies to improve courseware design toward usability may help articulate learners' more specific needs. Hence, this can be achieved with multimedia instruction and well designed user interface.

\section{Response towards Strategies}

In addressing the question of strategies that can enhance the courseware usage, the effectiveness of using multimedia instructions to replace text instructions were suggested as best method to improve usability and to acquiring knowledge. The general impression was that the media was appreciated. One expert used the term, time-saving to qualify media in the study. That is, it's much faster than using a text, through “...You gained more and are shown more when watching a video than you can read in a document and you know what you are looking for in advance".

Another respondent expressed the view through "This is about watching and mimicking what other people do. I think that is the key point for usability enhancement, and it requires much less effort". Another respondent expressed that "...It must have something to do with the combination of voices and pictures; I think it will help students to remember things easier".

Any student who suffered from both visual and hearing impairment (i.e. a disability concerned with readingwords and hearing) learning activities with multimedia instructions with voice and image display will be favorable.People with dyslexia dysfunction typically read at levels significantly lower than expected, despite having normal intelligence [15]. It was expressed that "Students are very fond of the films (multimedia instructions), because the multimedia can explain the courseware topics very clearly". Besides, “...The best way for students to learn is to see and listen. They prefer to see, listen, and write down at their own pace. That is what is called dyslectic approach"

To be able to meet the needs of these students, alternative learning tools would be a beneficial approach, both for the disabled and for the educational institutions. [9] accounts for individual profiles when it comes to learning preferences (i.e. preferring multimedia instruction via text or static graphics). [14] consider this issue of multimedia in the courseware as the visualize-verbalizer dimension.

More so, the attitudes towards this courseware were both comprehensive and profound. Before presenting the various viewpoints, it has to be mentioned that all multimedia modules were developed to compliment both e-learning and text instructions and dealt with tutorial instructions, which is comparable to the study of [8].

The respondents expressed a number of characteristics for multimedia instructional helpful for learning activities. They mentioned user interface as one of characteristic to enhance the usability of courseware. Also, [16] categorized multimedia modules into four groups of characteristics: navigation, content (i.e coherence between verbal and pictorial information), social presence, and learning effectiveness. Navigation has been part of multimedia instructional components, with respect to the quality of user control as an essential usability aspect [11]; [17]. The navigation in multimedia instructions provided the interactive commands, such as play, stop, pause, rewind and the possibility to move the lessons forward and backward. They also included status information related to file loading and time remaining. The following opinions were expressed about the navigation features:

"If you miss some points during the learning process, you only rewind and watch it again. You have all opportunities. It becomes like a lecture. Instead of closing the lecture page and open the reference links [to search a text book], we put it on standby and open the reference links, later it open back. I think it's close to that imagination" and"You are the controller, you can stop, and you can play again [the multimedia instructions] over and over again! It is very good"

\section{DISCUSSION AND CONCLUSION}

The purpose of this study was to gather users' feedback on the current implementation of distance learning on available courseware, including usability factors. In the study, the research dealt with practice rather than theory, while having in mind that practice embodies experimental and theoretical knowledge. The study has tried to uncover participants' attitudes toward courseware usage. The findings could be useful for formulating questions to guide supplementary studies that could provide deeper understanding of courseware usability strategies.

It is obvious that the participants of this study were different from typical respondents because they were all lectures from distance learning and professionally engaged in positions where the content of the study had essential. Therefore, according to [7], were respondents whose responding is interest lay in connected to their professions. In that sense, it is hardly to equate these groups of participants with ordinary respondents in the institutions.

The participants explicitly expressed that the courseware had beenbeneficial and flexible for their learning and teaching. Due to their experiences with the online activities in distance learning, where they developed new skillsand gained insight into various coursewares developing processes. These opinions are not unique to this group of participants.

[13] Concluded the following after implementing a similar courseware in institution: this courseware will present an avenue of greater student access to such high learning supports in the quest to promote deep learning and understanding of the subject matter.

The positive respond in regard to enhanced usability choice of courseware andthe feeling of accessibility, in regarding the course content taught gives the courseware approach an interestingperspective. The participants valued the unlimited access to the course content repository of teaching andlearning materials and being able to interact with it easily. 
The participants reflected over and gave meaningful feedbacks about the use of the multimediainstructions to improve courseware usability. The tendency was that participants had valid activity-based learning going on with themultimedia files during the courseware usage. Overall, they commented on how ease of navigation. Participants noted that those factors hada positive impact on their learning experiences.

A valuable finding of this study was that there are needs for multimedia instructional as usability strategies in courseware for distance learning and it were found helpful for both normal and disabled student. The fact remain that quite some students in distance learning are suffering from remarkable diversity of human abilities.It is suggested that implementation of multimedia strategies in courseware should be given a higher priority to cater for those diversity of human abilities, because it might help these students.

The enthusiasm with which this participant expressed her positive attitude towards that there is a need for studying the usability strategies for courseware in distance learning in Nigeria.Further research on the integrating appropriate usability strategies in courseware for broadening teaching and learning settings was required.

The feedback in general indicates a positive learning impact of the courseware when integrated with complementing usability strategies. Students valued the design of the courseware aswell as the design of the multimedia instructions with user interface factors (navigation, layout and structure).

The positive feedbacks in general underpin an assumption regarding usability strategies will improve the courseware usage and it will enhance quality education system as expressed by Mearoff [19]:

This study anticipates that this will increase the standard of distance learning in Nigeria. Also, distance learning will never be the dominant method of educating students. However, it will be a fixed part of the delivery system of higher education to improve the students' enrollment into tertiary institution.

\subsection{Conclusion}

The findings suggest that there are needs for usability strategies in courseware in Nigeria, and can besuccessfully implemented by considering the appropriated strategies for enhancing the motivation of learners towards courseware usage in distance learning programmes. This will provide a favorable transition to aneducational design viausing courseware for teaching and learning

Participants were interviewed to identify their attitudes towards the needs for usability strategies in courseware in distance learning, Nigeria. Multimedia instruction in courseware and the key matters in strategies factors of usability. Findings indicate that participants responded in favor of the courseware mainly because of it improved flexibility and enhanced content accessibility. Further, the usability strategies factors (ease of navigation, appropriate structureand layout) were identified as beneficial for enhancing the usage ofcourseware.

Even though, the number of participants in this study was rather small, the results gave some clear signify of the need for usability strategies in distance learning in Nigeria.

It is recommended that the findings of this study are followed by new studies to determine the most appropriate instructional interface component that will be usability strategies to be used by students in inclusive education system which involving other groups of respondents that are from distance learning.
Furthermore, it should be examined how integrating universality on multimedia instructional; such as multilayer, cued speech or sign language to user interface design, this could enhance strategies towards courseware usage. Such studies would serve to further explore the potentials of courseware usability.

\section{REFERENCE}

[1] Arksey, H., \& Knight, P. T. (999). Interviewing for social scientists: An introductory resource with examples. Sage.

[2] Creswell, J. W., Hanson, W. E., Plano, V. L. C., \& Morales, A. (2007). Qualitative research designs selection and implementation. The Counseling Psychologist, 35(2), 236-264.

[3] Garnham, C., \&Kaleta, R. (2002). Introduction to hybrid courses. Teaching with Technology Today, 8(6).

[4] Kabari, L., \&Ukpong, U. (2012). Creating an effective Elearning environment for Nigerian Polytechnic Educational System. Paper presented at the Adaptive Science \& Technology (ICAST), 2012 IEEE 4th International Conference on.

[5] Kay, J. (2001). Learner control. User modeling and useradapted interaction, 11(1-2), 111-127.

[6] Koohang, A. (2009). A learner-centred model for blended learning design. International Journal of innovation andlearning, 6(1), 77-91.

[7] Liotsios, K., Demetriadis, S., \&Pombortsis, A. (2006). Blended learning technologies in lifelong education: Lessons learnedfrom a case study. In K. T. W. Nejdl (Ed.), EC-TEL (pp. 634-639).

[8] Mackey, T. P., \& Ho, J. (2008). Exploring the relationships between Web usability and students' perceived learning in Web basedmultimedia (WBMM) tutorials. Computers \& Education, 50, 386-409.

[9] Mayer, R. E. (2003). The Promise of Multimedia Learning: using The Same Instructional Design Methods across Different Media. Learning and Instruction, 13(2), 125-139. doi:10.1016/S0959-4752(02)00016-6

[10] Miller, C., \& Bartlett, J. (2012). 'Digital fluency': towards young people's critical use of the internet. Journal of Information Literacy, 6(2), 35-55.

[11] Nielsen, J. (2002). Flash: 99\% bad. Retrieved from http://useit.com/alertbox/20001029.html

[12] Okonkwo, C. (2012). Assessment of challenges in developing self-instructional course materials at the National Open University of Nigeria. International Review of Research in Open and Distance Learning, 13(2), 221231.

[13] Olasina, G. (2013). Factors Motivating and Impeding Courseware Development in Nigeria. Paper presented at the Conference and Programme Chairs.

[14] Plass, J. L., Chun, D. M., Mayer, R. E., \& Leutner, D. (1998). Supporting visual and verbal learning preferences in a second language multimedia learning environment. Journal of Educational Psychology, 90, 25 \pm 36 .

[15] Pind, J. (1998). Advances in dyslexia research. Trends in Cognitive Science, 2(1), 1-2. 
[16] Rosenbaum, P.-E. L. (2013). Educational Design: Learners Attitudes Towards Blended Learning with Online Multimedia Instruction. International Journal of Learning and Teaching, 4(2), 42-61

[17] Tabbers, H. K., Martens, R. L., \& van Merrienboer, J. J. G. (2004). Multimedia instructions and cognitive load theory: Effect of modality and cueing. British Jorunal of Education Psychology, 74, 71-81.
[18] Young, G. (2002). Hybrid teaching seeks to end the divide between traditional and online instructions. Chronicle of HigherEducation, A33-A34.

[19] Zemsky, R., \&Maeroff, G. (2007). E-learning: Successes and failures. The Chronicle of Higher Education, 53(18), $1-7$. 